\title{
Phytoplankton and macrophyte contributions to littoral food webs in the Galician upwelling estimated from stable isotopes
}

\author{
Antonio Bode*, Maria Teresa Alvarez-Ossorio, Manuel Varela \\ Instituto Español de Oceanografía, Centro Oceanográfico de A Coruña, Apdo. 130, 15080 A Coruña, Spain
}

\begin{abstract}
The natural abundance of stable carbon and nitrogen isotopes was analysed in plankton and intertidal benthos at coastal sites of Galicia (NW Spain) to determine the relative importance of phytoplankton versus benthic macrophytes, and marine versus anthropogenic nutrients, in supporting littoral food webs in this upwelling ecosystem. Phytoplankton was significantly less enriched in heavy isotopes than most macrophytes (seagrasses and 3 classes of macroalgae). Nitrogen isotopes showed significant enrichment of primary consumers (zooplankton, benthic suspension feeders and deposit feeders) relative to primary producers. The average enrichment between trophic levels, however, was low $\left(\Delta \delta^{13} \mathrm{C}=+0.1 \%, \Delta \delta^{15} \mathrm{~N}=+1.4 \%\right)$, suggesting the prevalence of omnivory. The use of marine nitrogen was inferred from the low nitrogen isotope abundance values of phytoplankton and rhodophycea. In contrast, phaeophycea and chlorophycea displayed high nitrogen isotope enrichment, particularly at sheltered sites, suggesting the influence of anthropogenic nitrogen. The diets of benthic consumers reflected the local diversity of available sources, with a large influence of phytoplankton and marine nitrogen at open sea sites. Average contributions of phytoplankton to diet always exceeded $40 \%$ in the case of suspension feeders but were generally $<20 \%$ for deposit feeders. Estuarine macrophytes were generally $<10 \%$ of diet for both groups. Carbon isotopes indicated a significant contribution of macrophytes $(77 \%)$ to sinking particles. In contrast, most of the nitrogen of sinking particles and consumers was provided by marine sources. These results confirm the dominant role of marine nitrogen and phytoplankton in supporting littoral food webs in the Galician upwelling ecosystem, despite local inputs of anthropogenic nutrients.
\end{abstract}

KEY WORDS: Food web · Nitrogen · Stable isotopes · Upwelling · Phytoplankton · Macroalgae Resale or republication not permitted without written consent of the publisher

\section{INTRODUCTION}

Coastal marine ecosystems receive inorganic nutrients and organic matter from several sources. While the total input of external nutrients generally sets an upper limit to biological productivity, the diversity and relative importance of these sources determines the structure of local food webs and the fate of organic matter (Valiela 1995). For instance, estuaries are under the influence of rivers, coastal wetlands and the sea, each providing external (new) nutrients and organic matter (McClelland \& Valiela 1998, Cole et al. 2004). These sources support high levels of primary production, which is further sustained by the regeneration of nutrients inside the estuary (Horrigan et al. 1990,
Alvarez-Salgado et al. 1996, Kerner \& Spitzy 2001). In addition, continental waters near urban, industrial or agricultural areas generally carry considerable loads of anthropogenic nutrients, causing eutrophication in coastal systems (Cole et al. 2004). As a result, estuarine food webs are complex and based on a combination of benthic and planktonic primary producers, which in turn support a large diversity of consumers (McClelland \& Valiela 1998). Coastal areas not influenced by continental waters, however, depend mainly on marine nutrients. The productivity of these systems is regulated by oceanographic processes, such as upwelling or the seasonal alternation of stratification and mixing, fertilizing the euphotic layer. Phytoplankton is generally the main support for food webs in these systems, 
but when the shelf is relatively flat and shallow large populations of benthic macrophytes, such as kelp forests (Mann 1988, Duggins et al. 1989, Fredriksen 2003), may dominate the input of organic matter.

The relative importance of phytoplankton versus macrophytes as the support of food webs ultimately affects the use of the organic matter, as the former generally has lower refractory carbon content than the latter (Duarte \& Cebrián 1996). Changes in the nutrient sources are related to alterations in the dominance of primary producer types affecting the entire food web. For instance, the replacement of seagrass meadows by opportunistic macroalgae as the consequence of an increasing load of anthropogenic nitrogen is expected to accelerate the flow of nutrients through the food web (McClelland \& Valiela 1998). Because of the implications for coastal management, the sources of nutrients and the structure of food webs were studied in a large number of ecosystems, but mostly in estuaries (e.g. Valiela 1995). Few studies were made in areas with low influence of continental waters, such as rocky shores or kelp beds (Duggins et al. 1989, Fredriksen 2003), where the influence of anthropogenic nutrients is expected to be small.

The coast of Galicia (see Fig. 2) is at the northern limit of the influence of the Canary upwelling system (Wooster et al. 1976, Alvarez-Salgado et al. 2002). The effects of upwelling are amplified by the coastal morphology, as there are coastal inlets, or rias, that sustain high levels of biological productivity (Varela et al. 1984, Bode et al. 2004a,b). The rias are partially mixed estuaries with generally low inputs of continental water and major influence of shelf water (AlvarezSalgado et al. 1996, Prego et al. 1999). A large fraction of the organic matter produced after upwelling events is subsequently remineralised inside the rias and nearby shelf, further sustaining primary production. This mechanism explains the importance of regenerated production, unusual for an upwelling ecosystem (Alvarez-Salgado et al. 2002, Bode et al. 2004a). The rias also support large populations of macroalgae and seagrasses (Niell 1977a). Macroalgae in particular may be a significant source of organic matter for littoral food webs, not only through the detachment of vegetative parts at the end of summer and the release of reproductive cells near the coast (Niell 1977b) but also by the release of dissolved organic matter. Due to the high levels of primary production, the rias support intensive fisheries and aquaculture exploitation, notably mussel rafts (Figueiras et al. 2002). At the same time, most of the urban population of Galicia is located near the rias, which also support a heavy industrial use. Consequently, eutrophication was measured at some sites (Varela \& Prego 2003), although the large influence of the sea had probably reduced its effects at the regional scale. Previous studies suggest that upwelling is the main factor controlling the high levels of biological productivity of Galicia (Blanton et al. 1987, Alvarez-Salgado et al. 2002, Figueiras et al. 2002), but the relative contribution of the various sources of organic matter and inorganic nutrients to the sustaining of littoral food webs was not quantified. A recent study, however, pointed out the importance of estuarine microphytobenthic production for suspension and deposit feeders (Page \& Lastra 2003).

One of the most sensitive techniques to determine the relative importance of several nutrient sources to a food web is the measurement of the natural abundance of stable isotopes in the dominant organisms at key trophic levels. Because light isotopes are easier to mobilize than heavy ones, consumers are enriched in heavy isotopes compared to their prey (Minagawa \& Wada 1984, Vander Zanden \& Rasmussen 2001, Post 2002, McCutchan et al. 2003). This enrichment allows for the quantification of the relative contribution of prey with different isotopic composition to a given consumer diet. In addition, nutrients provided by different sources may have a characteristic isotopic signature that can be traced through the food web (Cole et al. 2004).

The objectives of the present study are (1) to estimate the contribution of phytoplankton and macrophytobenthos to littoral food webs in northern Galician rias, and (2) to determine local differences in nutrient sources related to the input of anthropogenic nutrients near large urban areas. For this purpose, the natural abundance of stable carbon and nitrogen isotopes in organisms representative of the main trophic levels was employed as a tracer of the relative importance of various nutrient sources along the littoral food web. A simplified food web, including 2 main nitrogen sources (coastal upwelling and anthropogenic), 2 types of primary producers (phytoplankton and macrophytes), 2 types of benthic primary consumers (suspension and deposit feeders) and a common predator was considered (Fig. 1). From this model we hypothesized the

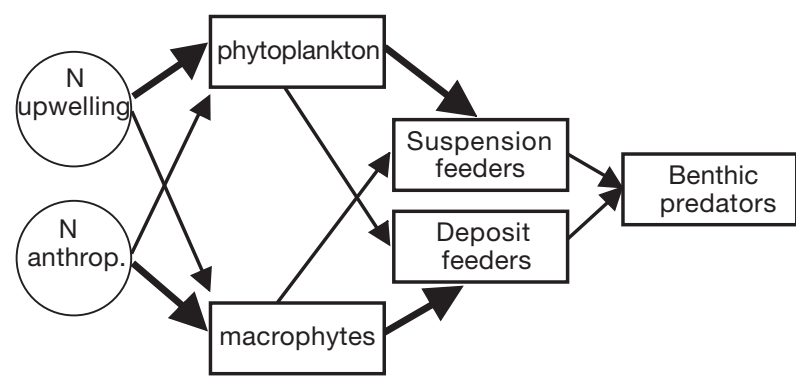

Fig. 1. Simplified model of the studied littoral food web. Arrows indicate the main fluxes with widths proportional to the hypothesized dominant pathways 
dominant fluxes of nutrients and organic matter for further examination during the study. In this way, nitrogen provided by coastal upwelling would be the main source for phytoplankton, while macrophytes would depend more on anthropogenic nitrogen. In turn, phytoplankton is expected to contribute to a large fraction of the diet of suspension feeders while deposit feeders would base their diet on macrophytes. These differences would be reflected in the isotopic composition of benthic consumers, including predators.

\section{MATERIALS AND METHODS}

Study area. Sampling of the various compartments of the model in Fig. 1 was made at different times during the period 1998-2002 to emphasize differences in isotopic composition. Samples of benthic species were collected in rocky shores of the intertidal domain during summer (July-August 2002) at various localities of the NW Iberian Peninsula (Fig. 2). The study area is characterised by rocky shores dominated by macrophyte and mussel beds. Sandy beaches and soft bottom communities were restricted to the inner parts of the rias. The sampling sites were chosen to represent environments with different influences of human activities. Mera was located in the Bay of A Coruña, an area under the influence of industry, fishing and recreational ports and surrounded by an human population of ca. 300000 people. Seselle was located in the nearby Ria de Ares, a coastal inlet not directly affected by industrial pollution and supporting less human population than the Bay of A Coruña. Finally, Pantin is a beach exposed to the sea and surrounded by agriculture and cattle fields with a sparse human population. There were 16 species of macrophytes and 10 species of animals collected (Table 1). Specimens were representative of the dominant primary producers in these ecosystems (Niell 1977a, Barbara \& Cremades 1996). Most of the macrophytes were sampled from rocks in the intertidal domain. Additional macrophyte and seagrass (Zosteraceae) samples were obtained from floating parts likely detached from nearby areas. Consumer species included suspension feeders, mainly Mytilus galloprovincialis, various deposit feeders, and the predator dogwhelk Nucella lapillus. Some species were only found at particular localities while others were sampled at all sites. The latter allowed for a comparative analysis among localities to test for the presence of nutrients at the base of the food web with a different isotopic composition.

Seston and plankton were sampled at locations near the benthos collection sites (Fig. 2). Sinking particles produced in the water column were collected at approximately monthly intervals between November 1997 and September 1999 at a site located between the Bay of A Coruña and the Ria de Ares. These samples were obtained by means of a particle interceptor trap of $6 \mathrm{~cm}$ diameter deployed for $24 \mathrm{~h}$ at $50 \mathrm{~m}$ depth and anchored to the sea floor. Details of sampling and limitations of this approach can be found in Bode et al. (1998). Zooplankton was collected between January 2000 and December 2001 at the same site using a $200 \mu \mathrm{m}$ mesh-size net towed between the surface and the bottom (Bode \& Alvarez-Ossorio 2004). Samples of phytoplankton were collected in spring (March 1999 and April 2000) by means of a $20 \mu \mathrm{m}$ mesh-size net

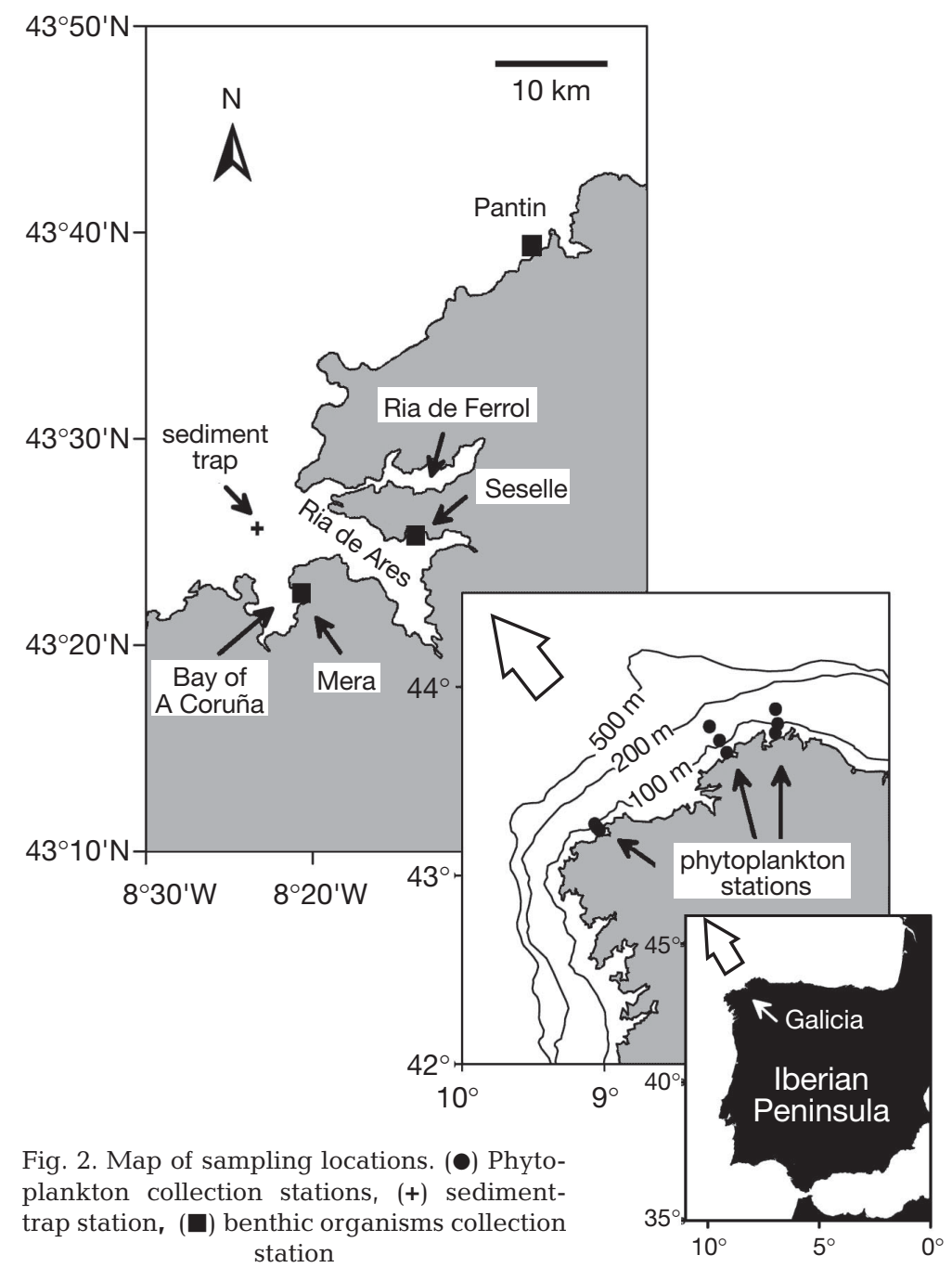


Table 1. Mean, SE, minimum and maximum values of $\delta^{13} \mathrm{C}$ and $\delta^{15} \mathrm{~N}$ of analysed benthic species. Trophic and taxonomic group, and sampling location of each species is also indicated. $\mathrm{n}=$ number of determinations; $-=$ not collected; $\mathrm{x}=$ collected

\begin{tabular}{|c|c|c|c|c|c|c|c|c|c|c|c|c|}
\hline \multirow{2}{*}{$\begin{array}{l}\text { Trophic group } \\
\text { Taxonomic group }\end{array}$} & \multicolumn{4}{|c|}{$\delta^{13} \mathrm{C}$} & \multicolumn{4}{|c|}{$\delta^{15} \mathrm{~N}$} & \multirow[t]{2}{*}{$\mathrm{n}$} & \multicolumn{3}{|c|}{ Locality } \\
\hline & Mean & SE & Min. & Max. & Mean & SE & Min. & Max. & & Mera & Seselle & Pantín \\
\hline \multicolumn{13}{|l|}{ Macrophytes } \\
\hline \multicolumn{13}{|l|}{ Chlorophyceae } \\
\hline Codium tomentosum & -14.0 & 0.5 & -15.2 & -12.8 & 7.7 & 0.9 & 5.8 & 9.9 & 6 & $\mathrm{x}$ & - & $\mathrm{x}$ \\
\hline Enteromorpha crinita & -14.4 & 0.1 & -14.6 & -14.2 & 9.1 & 0.1 & 9.0 & 9.2 & 3 & - & $\mathrm{x}$ & - \\
\hline Enteromorpha intestinalis & -16.4 & 2.8 & -21.2 & -11.6 & 7.9 & 0.3 & 6.9 & 9.3 & 3 & $\mathrm{x}$ & $\mathrm{x}$ & $\mathrm{x}$ \\
\hline Ulva rigida & -15.1 & 1.0 & -19.9 & -11.6 & 8.4 & 0.3 & 7.5 & 8.9 & 2 & $\mathrm{x}$ & $\mathrm{x}$ & - \\
\hline \multicolumn{13}{|l|}{ Phaeophyceae } \\
\hline Ascophyllum nodosum & -14.7 & 0.0 & -14.8 & -14.7 & 11.4 & 0.2 & 11.1 & 11.6 & 3 & $\mathrm{x}$ & - & - \\
\hline Bifurcaria bifurcata & -16.3 & 0.1 & -16.4 & -16.1 & 5.2 & 0.1 & 5.2 & 5.3 & 3 & _- & _- & $\mathrm{x}$ \\
\hline Cystoseira baccata & -16.6 & 0.4 & -19.0 & -15.5 & 6.8 & 0.3 & 5.5 & 7.9 & 9 & $\mathrm{x}$ & $\mathrm{x}$ & $\mathrm{x}$ \\
\hline Cystoseira ericoides & -18.4 & 0.1 & -18.5 & -18.2 & 6.8 & 0.1 & 6.7 & 6.9 & 3 & $\mathrm{x}$ & - & - \\
\hline Fucus ceranoides & -15.3 & 0.1 & -15.4 & -15.2 & 6.9 & 0.2 & 6.7 & 7.0 & 3 & - & $\mathrm{x}$ & - \\
\hline Fucus vesiculosus & -13.5 & 0.6 & -15.3 & -12.1 & 7.3 & 0.5 & 6.0 & 8.5 & 6 & $\mathrm{x}$ & - & $\mathrm{x}$ \\
\hline Saccorhiza polyschides & -13.3 & 0.1 & -13.5 & -13.2 & 6.5 & 0.1 & 6.4 & 6.6 & 3 & - & - & $\mathrm{x}$ \\
\hline \multicolumn{13}{|l|}{ Rhodophyceae } \\
\hline Gigartina acicularis & -16.8 & 0.4 & -17.6 & -16.2 & 4.6 & 0.2 & 4.2 & 4.8 & 3 & - & - & $\mathrm{x}$ \\
\hline Gymnogongrus crenulatus & -18.5 & 0.2 & -18.7 & -18.2 & 5.1 & 0.1 & 5.0 & 5.2 & 3 & - & - & $\mathrm{x}$ \\
\hline Mastocarpus stellatus & -17.0 & 0.5 & -18.0 & -16.2 & 5.2 & 0.0 & 5.1 & 5.3 & 3 & - & - & $\mathrm{x}$ \\
\hline \multicolumn{13}{|l|}{ Zosteraceae } \\
\hline Zostera marina & -9.1 & 0.1 & -9.3 & -9.0 & 5.9 & 0.0 & 5.8 & 6.0 & 3 & - & $\mathrm{x}$ & - \\
\hline Zostera noltii & -12.3 & 0.6 & -14.6 & -10.5 & 5.6 & 0.4 & 4.3 & 7.1 & 5 & $\mathrm{x}$ & $\mathrm{x}$ & - \\
\hline \multicolumn{13}{|l|}{ Suspension feeders } \\
\hline \multicolumn{13}{|l|}{ Cirripeda } \\
\hline Balanus perforatus & -18.2 & 0.1 & -18.4 & -17.8 & 6.9 & 0.0 & 6.9 & 7.0 & 4 & - & - & $\mathrm{x}$ \\
\hline \multicolumn{13}{|l|}{ Bivalvia } \\
\hline Mytilus galloprovincialis & -18.3 & 0.2 & -19.6 & -17.4 & 6.8 & 0.2 & 4.6 & 8.1 & 20 & $\mathrm{x}$ & $\mathrm{x}$ & $\mathrm{x}$ \\
\hline \multicolumn{13}{|l|}{ Deposit feeders } \\
\hline \multicolumn{13}{|l|}{ Gastropoda } \\
\hline Gibbula umbilicalis & -16.5 & 0.2 & -18.3 & -15.2 & 7.9 & 0.2 & 6.3 & 9.0 & 15 & $\mathrm{x}$ & $\mathrm{x}$ & $\mathrm{x}$ \\
\hline Littorina littorea & -17.5 & 0.3 & -18.6 & -15.4 & 8.0 & 0.2 & 7.2 & 9.0 & 11 & - & $\mathrm{x}$ & - \\
\hline Monodonta lineata & -16.5 & 0.2 & -17.8 & -15.5 & 8.1 & 0.2 & 6.5 & 9.7 & 20 & $\mathrm{x}$ & $\mathrm{x}$ & $\mathrm{x}$ \\
\hline Patella intermedia & -15.8 & 0.2 & -16.3 & -15.1 & 9.4 & 0.5 & 8.1 & 11.0 & 6 & - & $\mathrm{x}$ & - \\
\hline Patella vulgata & -18.0 & 0.4 & -19.6 & -15.9 & 6.7 & 0.2 & 6.3 & 7.5 & 7 & - & - & $\mathrm{x}$ \\
\hline \multicolumn{13}{|l|}{ Isopoda } \\
\hline Idotea balthica & -16.2 & 0.3 & -16.7 & -15.3 & 8.3 & 0.1 & 7.9 & 8.5 & 5 & $\mathrm{x}$ & $\mathrm{x}$ & - \\
\hline Sphaeroma serratum & -14.4 & 0.4 & -15.3 & -13.9 & 8.3 & 0.1 & 8.1 & 8.5 & 3 & $\mathrm{x}$ & - & - \\
\hline \multicolumn{13}{|l|}{ Predator } \\
\hline \multicolumn{13}{|l|}{ Gastropoda } \\
\hline Nucella lapillus & -17.3 & 0.2 & -17.9 & -16.1 & 7.7 & 0.2 & 6.9 & 8.6 & 11 & - & $\mathrm{x}$ & $\mathrm{x}$ \\
\hline
\end{tabular}

from the surface to ca. $5 \mathrm{~m}$ from the bottom, or to a maximum depth of $100 \mathrm{~m}$ (Bode et al. 2003). Phytoplankton samples were selected after screening the samples through a $200 \mathrm{~m} \mu \mathrm{m}$ mesh. The material collected by the traps and nets was filtered through glass-fibre filters (Whatman $\mathrm{GF} / \mathrm{F})$ and dried $\left(60^{\circ} \mathrm{C}\right)$ prior to stable isotope determinations.

Isotopic analyses. All specimens were carefully rinsed with filtered seawater to remove debris and sediments. Both basal and distal parts of the macrophytes were collected and combined for isotopic analysis to obtain a pooled value of all resources available to consumers, as isotopic signatures are known to vary within the thallus (Fredriksen 2003). Epiphytes were removed from macrophytes before freezing $\left(-20^{\circ} \mathrm{C}\right)$ for preservation until isotopic analysis. Live animals were allowed to empty their guts in clean local seawater for several hours. Afterwards they were rinsed with distilled water and frozen. Maximum length $( \pm 1 \mathrm{~mm})$ of animal specimens was recorded to account for a potential size-dependence of isotopic composition. Before isotopic analysis samples were thawed, the soft parts of animals were carefully removed from the shells, and all samples were freeze-dried and ground to a fine powder. No acidification was applied to the samples to avoid alterations in the isotopic signal (Jacob et al. 
2005). Aliquots of each sample were fed into an elemental analyser (Carlo Erba CHNSO 1108) coupled to an isotope-ratio mass spectrometer (Thermo Finnigan Mat Delta Plus) to obtain carbon and nitrogen content and the relative abundance of ${ }^{13} \mathrm{C}$ and ${ }^{15} \mathrm{~N}$ isotopes. Natural abundance values are expressed as:

$$
\delta X=\left[\left(R_{\text {sample }} / R_{\text {std }}\right)-1\right] \times 1000
$$

where $\delta X$ is $\delta^{13} \mathrm{C}$ or $\delta^{15} \mathrm{~N}, R_{\text {sample }}$ is the ratio between ${ }^{13} \mathrm{C}:{ }^{12} \mathrm{C}$ or ${ }^{15} \mathrm{~N}:{ }^{14} \mathrm{~N}$ in the sample and $\mathrm{R}_{\text {std }}$ is a calibrated standard. Natural abundance values are reported relative to VPDBS (Vienna Pee-Dee Belemnite Carbonate Standard, $\left.{ }^{13} \mathrm{C}\right)$ or atmospheric nitrogen $\left({ }^{15} \mathrm{~N}\right)$. Precision of both $\delta^{13} \mathrm{C}$ and $\delta^{15} \mathrm{~N}$ was better than $0.03 \%$ while the corresponding coefficient of variation of triplicate analysis of samples was always $<2 \%$.

Food web analysis. The analysis of the food web in Fig. 1 was made by estimation of the potential contribution of the different food sources to the diet of benthic consumers. For this purpose we employed models taking into account the average isotopic composition of sources and consumers at each sampling site. The general model employed was a linear mixing model of the type:

$$
\delta X_{\text {consumer }}=\Sigma f_{i}\left(\delta X_{i}+\mathrm{I}\right)
$$

where the isotopic composition of the consumer $\left(\delta X_{\text {consumer }}\right)$ was a linear function of the fractional contribution to the diet $\left(f_{i}\right)$ and of the isotopic composition $\left(\delta X_{i}\right)$ of each food source $i$. The isotopic composition of the sources was increased by a constant (I) representing the isotopic enrichment between adjacent trophic levels (trophic fractionation or trophic shift). This general model was applied to the estimation of the diets of primary benthic consumers (suspension feeders and deposit feeders) from the average $\delta X_{i}$ values of multiple sources using the program IsoSource (Phillips \& Gregg 2003). As there are multiple solutions that satisfy Eq. (2), the program computes all possible combinations of each source contribution by small increments ( $1 \%$ in our case) to average $\delta X_{\text {consumer }}$ values. A small tolerance interval $( \pm 0.2 \%$ in our case $)$ was allowed for both $\delta^{13} \mathrm{C}$ and $\delta^{15} \mathrm{~N}$. The program also provides a measure of variability by computing the frequency of the feasible solutions.

The diet of the benthic predators considered in this study was estimated from the contribution of both suspension feeders and deposit feeders. In this particular case, independent estimates were made using $\delta^{13} \mathrm{C}$ or $\delta^{15} \mathrm{~N}$ values and the program Isoerror (Phillips \& Gregg 2001). The variability of the estimated diets was computed by taking into account the measured variability in $\delta X_{i}$. Final results of diet contributions were reported as the average of prey contributions to carbon and nitrogen.

\section{RESULTS}

\section{Isotopic composition}

Benthic macrophytes showed a large range of both $\delta^{13} \mathrm{C}$ and $\delta^{15} \mathrm{~N}$ values, exceeding those of fauna (Table 1). In contrast, samples of plankton and sinking particles were comparatively less variable (Fig. 3). Extreme values were found in some species, such as the Phaeophyceae Ascophyllum nodosum or Zostera spp., which were associated to estuarine habitats. Excluding outliers (values exceeding 1.5 times the interquartile range), mean $\delta^{13} \mathrm{C}$ values of macrophytes were signifi-
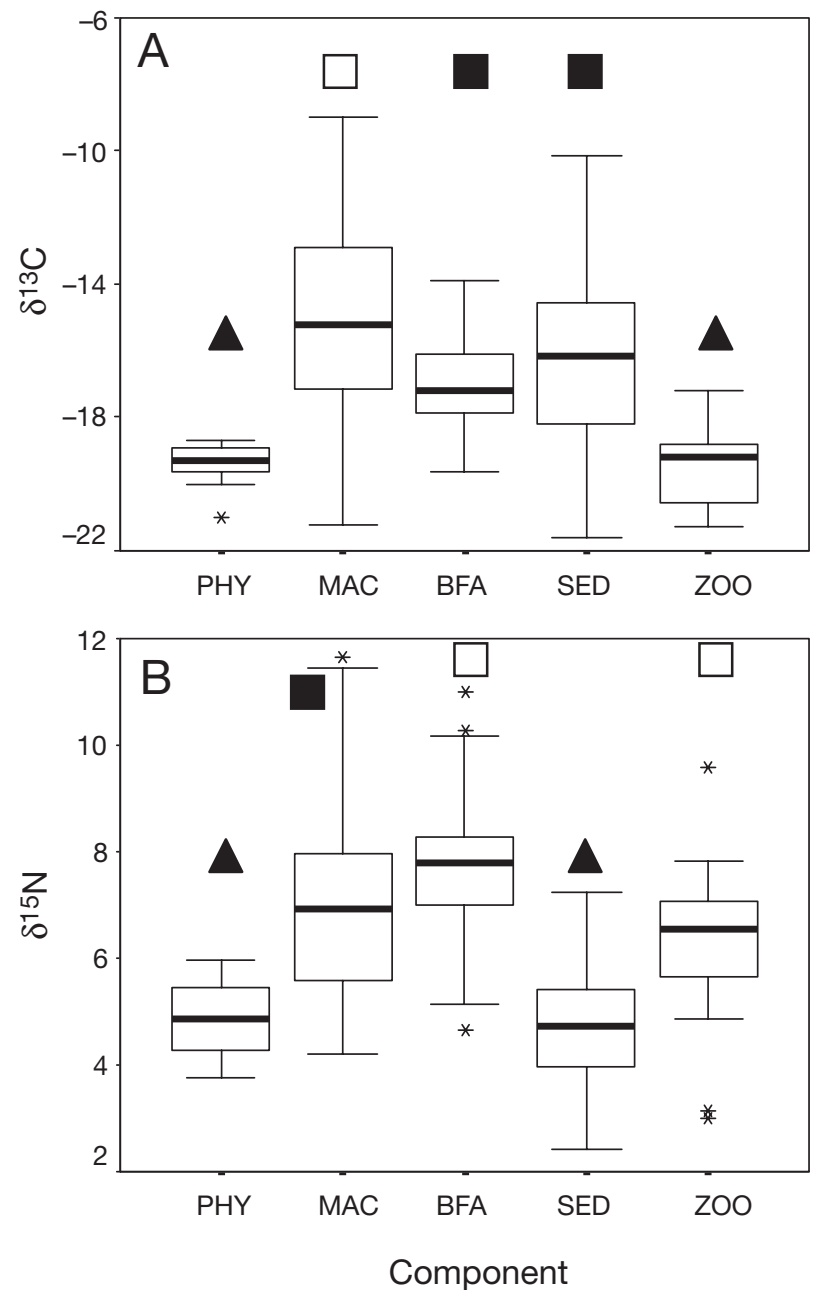

Fig. 3. Box-and-whisker plots of (A) $\delta^{13} \mathrm{C}$ and (B) $\delta^{15} \mathrm{~N}$. Thick horizontal line indicates the median, box includes interquartile range, and whiskers mark range of data (excluding outliers). $*=$ Outliers( $>1.5$ times interquartile range). Open and closed squares and triangles indicate non-significant mean values (excluding outliers as determined by ANOVA and Dunnett-C- tests $\mathrm{p}<0.05)$. PHY = phytoplankton $(\mathrm{n}=6), \mathrm{MAC}$ $=$ macrophytes $(\mathrm{n}=70), \mathrm{BFA}=$ benthic fauna $(\mathrm{n}=95), \mathrm{SED}=$ sinking particles $(\mathrm{n}=25), \mathrm{ZOO}=$ zooplankton $(\mathrm{n}=21)$ 
cantly larger than those of other categories (ANOVA, $\mathrm{p}<0.001$, and Dunnett's- $C$-test, $\mathrm{p}<0.05$ ), including benthic consumers, sinking particles and plankton (Fig. 3A). Only when considering $\delta^{15} \mathrm{~N}$ of benthic fauna and zooplankton values were significantly higher than those of primary producers and sinking particles (Fig. 3B), indicating the enrichment of consumers in heavy $\mathrm{N}$ isotopes. These results indicate a clear separation between planktonic and benthic primary producers using nitrogen isotopes, as macrophytes were enriched in ${ }^{15} \mathrm{~N}$ compared to phytoplankton. In addition, there was a difference in the apparent trophic shift between mean values of primary producers and consumers in plankton $\left(\Delta \delta^{13} \mathrm{C}=+0.1 \%\right.$, $\Delta \delta^{15} \mathrm{~N}=+1.4 \%$ o) and in benthos $\left(\Delta \delta^{13} \mathrm{C}=-1.9 \%, \Delta \delta^{15} \mathrm{~N}=+0.7 \%\right.$ )

Zosteraceae was the group of benthic macrophytes with the highest $\delta^{13} \mathrm{C}$, while mean values of all macroalgal groups were equivalent and similar to those of some benthic consumers (Fig. 4A). Only suspension feeders showed $\delta^{13} \mathrm{C}$ values significantly lower than those of other faunal or macrophyte groups. These results contrast with those of $\delta^{15} \mathrm{~N}$ indicating equivalent values for all benthic consumer groups, while macrophyte groups differed significantly (Fig. 4B). Chlorophyceae had the highest mean $\delta^{15} \mathrm{~N}$, followed by Phaeophyceae and Zosteraceae, while Rhodophyceae displayed the lowest values. Therefore, a clear separation of macrophytes can be made using isotopic signatures, suggesting the preferential use of several nitrogen sources by the main groups. In turn, the combined use of various nutrient sources by benthic consumers would explain the relative homogeneity in their isotopic values when averaged for all sampling sites.

\section{Local differences in isotopic composition}

Species present in several sampling sites allowed for the identification of differences in nutrient sources. In macrophytes, local differences were more marked with $\delta^{15} \mathrm{~N}$ than with $\delta^{13} \mathrm{C}$ (Fig. 5), although Enteromorpha intestinalis samples from Mera contained a higher proportion of both heavy isotopes than those from other localities. Cystoseira baccata displayed a significant gradient of decreasing enrichment in $\delta^{15} \mathrm{~N}$ from the urban site in Mera to the open sea in Pantin. In contrast, the samples of Zostera noltii collected in Mera and Seselle (there were no Zosteraceae in Pantin) had the same isotopic composition.

When considering benthic fauna, no significant correlation was found between individual size and either $\delta^{13} \mathrm{C}$ or $\delta^{15} \mathrm{~N}(\mathrm{p}>0.05)$. In this way, the effect of size can be considered as negligible, as all species showed isotopic signatures significantly lower in Pantin than
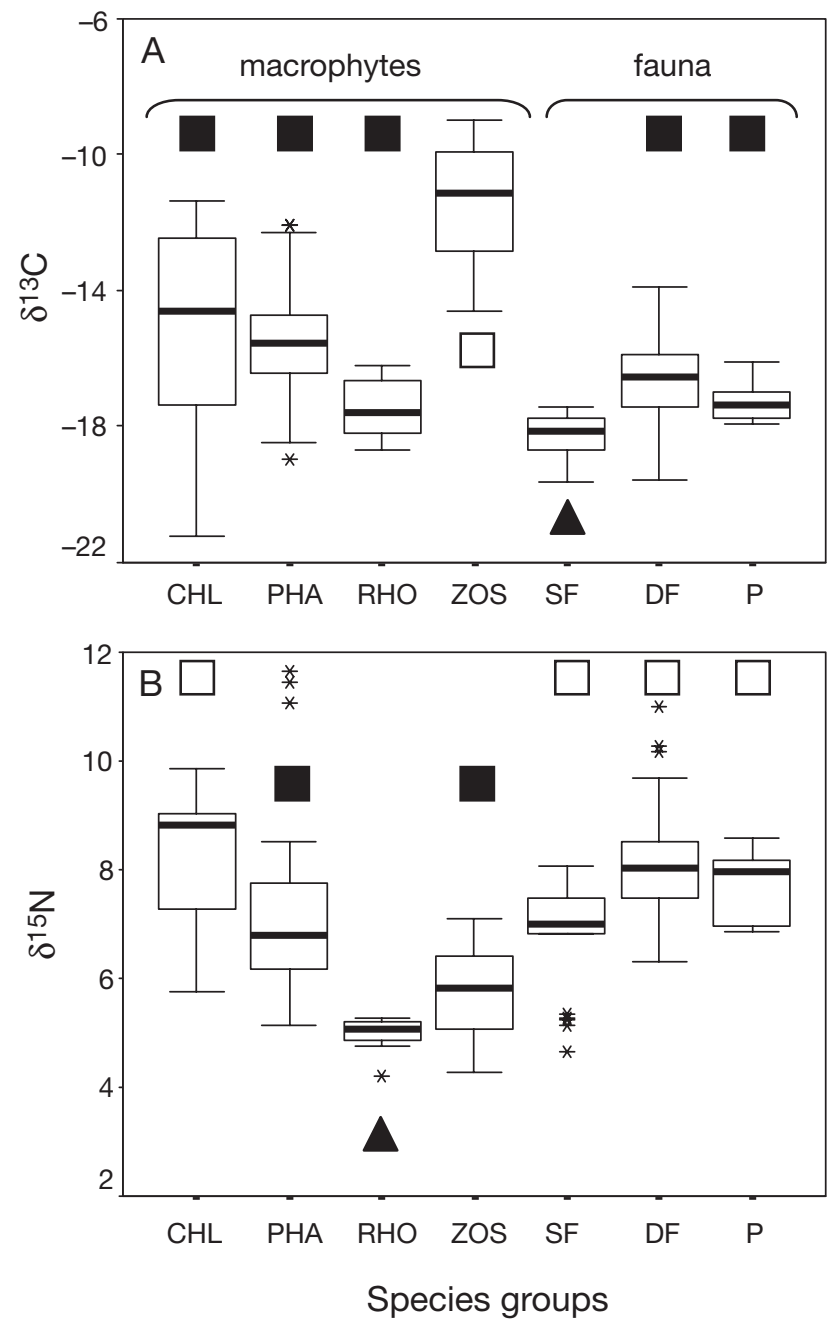

Fig. 4. Box-and-whisker plots of (A) $\delta^{13} \mathrm{C}$ and (B) $\delta^{15} \mathrm{~N}$ for various benthic species groups. Open and closed squares and triangles indicate significant differences in mean values (excluding outliers (*) as determined by ANOVA and Dunnett's- $C$-tests $\mathrm{p}<0.05$ ). $\mathrm{CHL}=$ Chlorophyceae, $\mathrm{PHA}=$ Phaeophyceae, RHO = Rhodophyceae, ZOS = Zosteraceae, SF = suspension feeders, $\mathrm{DF}=$ deposit feeders, $\mathrm{P}=$ predators . For $n$ see Table 1

those observed in the localities inside the rias (Fig. 6). Furthermore, the differences in $\delta^{15} \mathrm{~N}$ between localities were consistent in species representative of all consumer groups: suspension feeders Mytilus galloprovincialis, deposit feeders Gibbula umbilicalis and Monodonta lineata, and predators Nucella lapillus. These results suggest the dominance of different nutrient sources in localities inside the rias compared to the open sea site. Nutrients inside the rias would be more enriched in heavy isotopes than those from the open sea, and would produce the higher enrichment in both primary producers and consumers found in the former. 

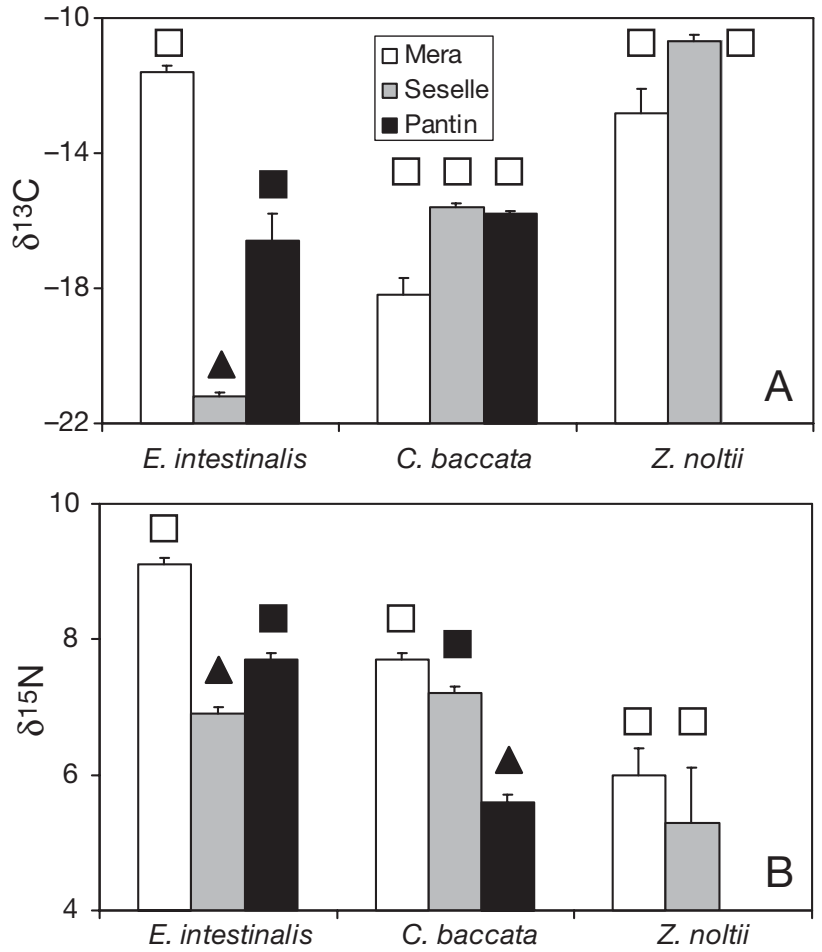

Fig. 5. Enteromorpha intestinalis, Cystoseira baccata and Zostera noltii. Mean $+\mathrm{SE}$ (A) $\delta^{13} \mathrm{C}$ and (B) $\delta^{15} \mathrm{~N}$ values by sampling locality. Significant differences between sites indicated by open and closed squares and triangles (ANOVA and Dunnett's- $C$-tests, $\mathrm{p}<0.05$ )

\section{Food webs}

The low isotopic enrichment found between benthic primary producers and consumers suggests that these consumers obtain a significant fraction of their nutrients from other sources. Therefore, to estimate the contribution of the potential food sources to benthic consumers, we employed mean $\delta^{13} \mathrm{C}$ and $\delta^{15} \mathrm{~N}$ enrichment values between trophic levels equivalent to those found between phyto- and zooplankton, by assuming that these trophic shifts represent the isotopic increase between primary producers and primary consumers characteristic of the studied ecosystem. The simplified food webs obtained for each sampling site accounted for the large diversity of food sources in Mera and Seselle, and the relatively low diversity in Pantin (Fig. 7). Estuarine macrophytes Zosteraceae and Ascophyllum nodosum were plotted separately as they have characteristic signatures that can be traced in consumers. Phytoplankton and Rhodophyceae were included in all local food webs, as they are assumed to depend on marine nutrients; the former because its samples were collected in the open sea, whereas the latter, although sampled only in Pantin, contains
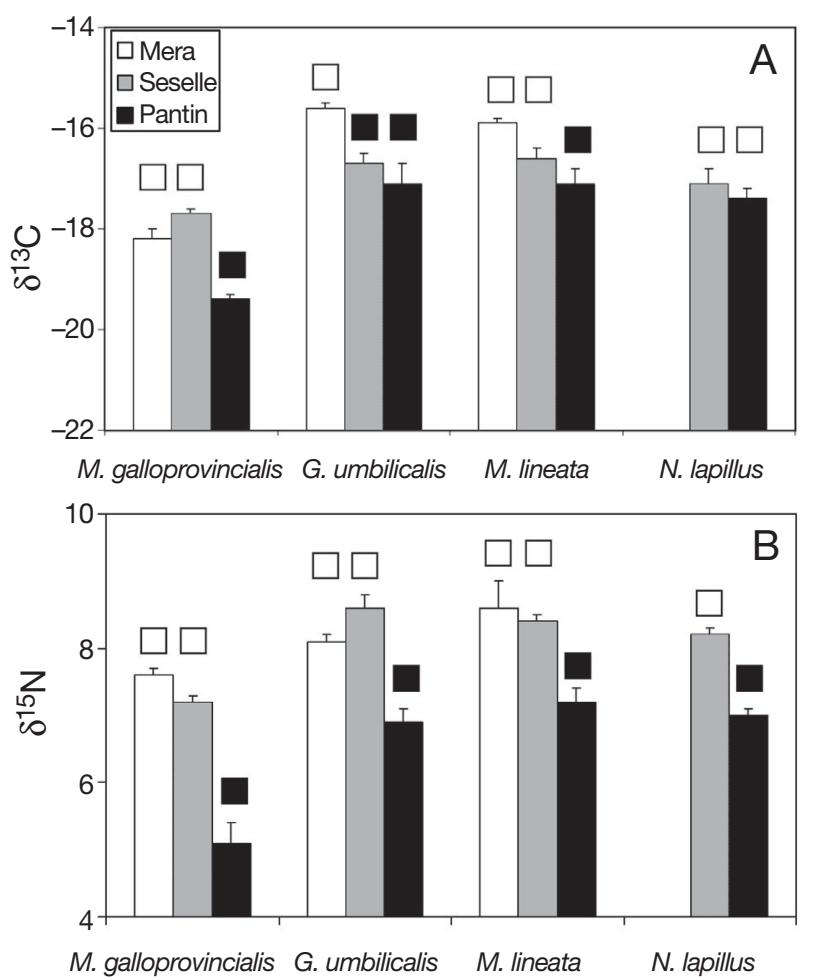

Fig. 6. Mytilus galloprovincialis, Gibbula umbilicalis, Monodonta lineata and Nucella lapillus. Mean + SE (A) $\delta^{13} \mathrm{C}$ and (B) $\delta^{15} \mathrm{~N}$ values by sampling locality. Significant differences between sites indicated by open and closed squares (ANOVA and Dunnett's- $C$-tests, $\mathrm{p}<0.05$ )

macrophyte species inhabiting lower intertidal and subtidal habitats. This assumption is supported by the similarity in $\delta^{15} \mathrm{~N}$ values displayed by both phytoplankton and rhodophytes.

According to their position in the $\delta^{13} \mathrm{C}$ versus $\delta^{15} \mathrm{~N}$ plots, deposit feeders in Mera would receive a balanced contribution of up to 6 food sources (Fig. 7A). In contrast, suspension feeders were located inside the mixing triangle delimited by phytoplankton, Rhodophyceae and Phaeophyceae (the latter excluding Ascophyllum nodosum), suggesting a negligible contribution of materials derived from other food sources, such as Zosteraceae, Chlorophyceae or the estuarine Phaeophyceae A. nodosum. A comparable food web was obtained for Seselle, but in this case the contribution of Zosteraceae was very small, and phytoplankton and all macroalgal groups were the main food sources for consumers (Fig. 7B). Finally, Pantin showed a relatively simple food web, with major contributions of phytoplankton, Chlorophyceae and Rhodophyceae to the composition of deposit feeders (Fig. 7C). In this case, the position of suspension feeders in the $\delta^{13} \mathrm{C}$ versus $\delta^{15} \mathrm{~N}$ plot was near, but outside, the polygon delimited by the values of the identified food sources. 


\section{Consumer diets}

Using the simplified food webs and the linear mixing models of sources delimiting the polygons in Fig. 7, the average contribution of the different food sources to the consumers were estimated for each locality. In


Fig. 7. Plot of mean $( \pm \mathrm{SE}) \delta^{13} \mathrm{C}$ versus $\delta^{15} \mathrm{~N}$ values for selected ecosystem components in (A) Mera, (B) Seselle and (C) Pantin (see Figs. $3 \& 4$ for component names). ASC $=$ Ascophyllum nodosum. Potential food sources for consumers linked by lines. Trophic shifts were applied between food sources and consumers of +0.1 and $+1.4 \%$ for $\delta^{13} \mathrm{C}$ and $\delta^{15} \mathrm{~N}$, respectively the case of suspension feeders, phytoplankton always accounted for $>40 \%$ of their diet (Fig. 8A), with contributions of macrophyte-derived food particles generally $<20 \%$. Even at sites with high diversity of potential food types, as in Mera or Seselle, the contribution of estuarine macrophytes was $<10 \%$. Since the mean $\delta^{15} \mathrm{~N}$ value of suspension feeders at Pantin was slightly lower than that of phytoplankton, it can be assumed that these consumers do not depend on macrophytes at this open sea site.

Deposit feeder diets were more variable among sampling sites (Fig. 8B). They included mainly macrophytes (mostly Chlorophyceae) at sites inside the rias, but phytoplankton accounted for $>40 \%$ at Pantin. All food sources showed a similar contribution in Mera (between 10 and $20 \%$ ), while macrophytes formed the bulk of the diet in Seselle (>95\%). Chlorophyceae were more important than Phaeophyceae for both deposit and suspension feeders at Seselle, but only for deposit feeders at Pantin. In Mera, Phaeophyceae con-
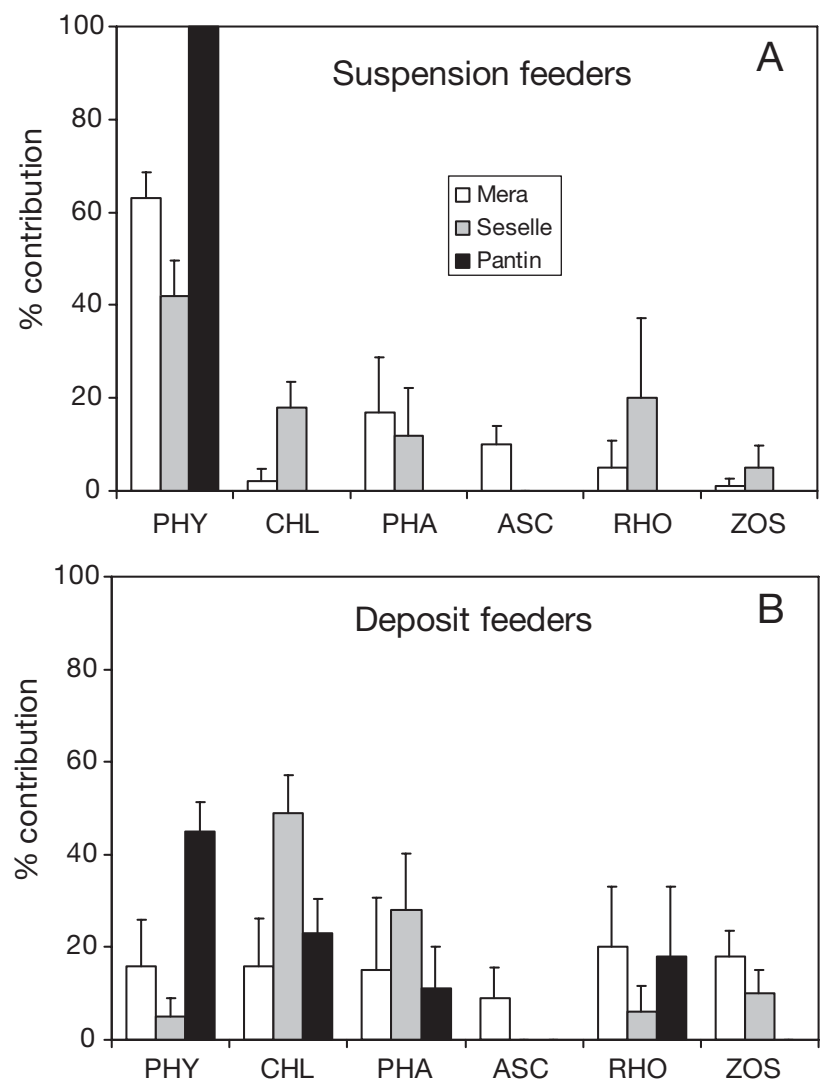

Fig. 8. Values of mean + SD \% contributions of different food sources to biomass of (A) suspension feeders and (B) deposit feeders in sampling localities (see Figs. 3 \& 4 for component names). ASC $=$ Ascophyllum nodosum. Contributions were estimated by a mixing model from mean $\delta^{13} \mathrm{C}$ and $\delta^{15} \mathrm{~N}$ values of food sources and consumers (IsoSource, Phillips \& Gregg 2003) 


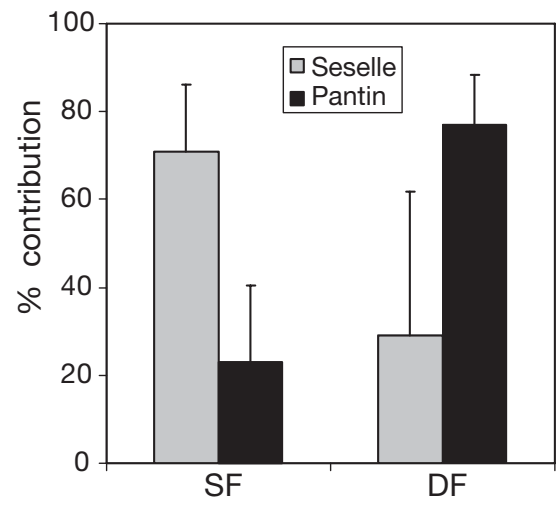

Fig. 9. Nucella lapillus. Mean + SD contributions (\%) of prey to biomass of this benthic predator in sampling localities. Plotted values are mean values of the estimations made independently for carbon and nitrogen by using a linear mixing model taking into account the measured variability of $\delta^{13} \mathrm{C}$ and $\delta^{15} \mathrm{~N}$ (Isoerror, Phillips \& Gregg 2001)

tributed more than Chlorophyceae to the diet of suspension feeders (Fig. 8).

In the case of the predator (Nucella lapillus), the estimation of the contributions by their prey was simplified, as they were only 2 types of potential prey: deposit- and suspension feeders. However, the average trophic shift observed for carbon was higher $\left(\Delta \delta^{13} \mathrm{C}\right.$ $=+0.4 \%$ ) , and that for nitrogen lower $\left(\Delta \delta^{15} \mathrm{~N}=+0.5 \%\right.$, than average values applied for primary consumers in Fig. 7. Using the observed trophic shift values to estimate the diet of the predator produced apparent differences in mean contribution of prey, as suspension feeders seemed to be mainly consumed in Seselle (Fig. 9), but these difference were not significant when taking into account the variability in the isotopic determinations (ANOVA, $\mathrm{p}>0.05$ ). Thus, on average, $N$. lapillus diet is composed by equivalent amounts of both prey types. The variability observed at each sampling site could be attributed to the availability of a particular type of prey rather than to particular preferences of the predator.

\section{DISCUSSION}

\section{Sources of organic matter}

This study showed clear differences in the stable isotope composition of the main primary producers of the littoral food web in northern Galicia. Phytoplankton contained a lower proportion of heavy isotopes than macrophytes, and the latter also showed characteristic isotopic signatures for each of the main taxonomic groups. Physiological causes and changes in the dominant sources of inorganic nutrients are the basis for the differentiation. Among the former, the higher $\delta^{13} \mathrm{C}$ values of macrophytes compared to those of phytoplankton were related to the thickness of the boundary water layer, which affects the diffusion of nutrients into the cells and causes fractionation of heavy isotopes (France 1995, Raven et al. 2002). Low growth rates, typical of plants living in low light, subtidal environments (such as most rhodophyta) also cause characteristically low $\delta^{13} \mathrm{C}$ values because of a reduction in the active uptake of inorganic carbon (Kübler \& Raven 1994). In addition, seagrasses have higher $\delta^{13} \mathrm{C}$ values than those of phytoplankton and macrophytes (McClelland \& Valiela 1998). Similarly, a different origin of the dominant nitrogen source would leave a characteristic isotopic signature in the primary producers, as sewage derived nitrogen is enriched in ${ }^{15} \mathrm{~N}$ relative to marine nitrogen (Cole et al. 2004, Savage \& Elmgren 2004).

Samples representing phytoplankton in our study were collected in spring to reduce the presence of nonphytoplanktonic particles, as the main blooms are produced during this season (Bode et al. 2003, 2004a,b). Because phytoplankton growth during spring is mostly based on nitrate (Bode et al. 2004a), these samples can be considered representative of pelagic primary production derived from upwelling nutrients. Subsequent growth of phytoplankton during summer and fall is based on regenerated nitrogen, except during episodic upwelling events. The use of alternative nutrient sources, however, may affect the isotopic signature of phytoplankton, as illustrated in other systems (Savoye et al. 2003). In this way, during the initial stages of a bloom, the preferential assimilation of ${ }^{14} \mathrm{~N}$ by phytoplankton causes enrichment in the remaining dissolved inorganic nitrogen (Montoya \& McCarthy 1995). When most of the initial nitrogen is exhausted from the dissolved phase, phytoplanktonic ${ }^{15} \mathrm{~N}$ increases by uptake of the enriched nitrogen. In the study area, this was indicated by the significant isotopic enrichment in zooplankton as nitrate concentration decreased during most of the spring and early summer (Bode \& Alvarez-Ossorio 2004). Thus, the isotopic abundance in our phytoplankton samples represents the annual minimum due to the predominant use of new nitrate. In contrast, macrophytes would be at maximum levels of isotopic enrichment, since all specimens were collected in summer, when maximum growth occurs. In this way, studies in kelp forests have shown summer peaks of isotopic enrichment in macroalgae (Fredriksen 2003).

The isotopic signatures of phytoplankton and macrophytes represent 2 end-members of the main sources of organic matter for consumers in the study area. Both are the main contributors to primary production in Galician waters, with equivalent values that may 
exceed $1 \mathrm{~kg} \mathrm{C} \mathrm{m}^{-2} \mathrm{yr}^{-1}$ in some rias (Varela et al. 1984). This contrasts with the low contribution of microphytobenthos, which in intertidal mudflats amounted to $79 \mathrm{~g}$ $\mathrm{C} \mathrm{m}{ }^{-2} \mathrm{yr}^{-1}$ (Varela \& Penas 1985). As most of the sampling sites of this study are rocky shores, microphytobenthos would be relatively less important than other primary producers for primary consumers. Furthermore, measurements of $\delta^{15} \mathrm{~N}$ in some samples of microflora and detritus scraped off the rocks in Mera (mean $\pm \mathrm{SD}=6.6 \pm 0.4 \%$, $\mathrm{n}=3$ ) were within the range of values obtained for macrophytes, thus suggesting that the values obtained for the latter are representative of a pooled contribution of macroalgae and associated microflora.

Dominance of particles derived from macrophytes over those derived from phytoplankton in the seston can be inferred from the isotopic composition of sinking particles off A Coruña (Fig. 3), by assuming no isotopic fractionation in fresh detritus and a linear mixing model of the 2 end-members. Particles collected in the traps (mean $\delta^{13} \mathrm{C}=-16.2 \%$ ) would contain $77 \%$ of carbon from macrophytes $\left(\delta^{13} \mathrm{C}=-15.2 \%\right)$ and only $23 \%$ from phytoplankton $\left(\delta^{13} \mathrm{C}=-19.5 \%\right)$. Bacterial degradation of phytoplankton carbon in the particles would have required a large isotopic fractionation (>3\%), unusually high for sinking particles near the surface (Williams et al. 1992). The average $\delta^{15} \mathrm{~N}$ value of sinking particles, however, was close to that of phytoplankton, suggesting that most of macrophyte nitrogen was lost during plant decay and particle formation. Similar results were reported for sinking particles near kelp forests (Fredriksen 2003). These estimations imply a high contribution of macrophytes to coastal sediments in the form of particulate organic carbon, although the high variability of isotopic signatures in both macrophytes and sinking particles may indicate large variations along the seasonal cycle. In this way, measurements obtained with sediment traps in the study area revealed large variations in particle composition and sinking rates, which were related to phytoplankton blooms and resuspension of seabed sediments in winter (Bode et al. 1998).

\section{Food webs: phytoplankton versus macrophyte inputs}

Despite the high contribution of macrophyte carbon to sinking particles, our study shows that most intertidal consumers rely on organic matter derived from phytoplankton. Also, the reconstructed food webs indicate a low contribution of estuarine organic matter. These results could be affected by the various assumptions necessary for the models employed. First, as discussed above, we assumed that phytoplankton and some groups of macrophytes were the main sources of organic matter for the food web in the study area, while the potential contribution of other sources was negligible. Second, we used local values of natural abundance of isotopes in macrophytes to account for the spatial variability in the origin of nutrient sources but only spring values for phytoplankton. While this choice maximized the expected differences between sources, it is known that the isotopic signature at the base of the food web in upwelling ecosystems varies according to the input of new nutrients (O'Reilly et al. 2002). This variability mainly affects the computation of diets and trophic positions in long-living consumers (such as fish) when using only concurrent measurements in both sources and consumers, since the latter integrate variations in the isotopic composition of diet items over long time periods. The isotopic composition of both suspension feeders and deposit feeders integrate short-term variability in the signature of phytoplankton and phytobenthos, and these consumers are often used as a reference baseline for the computation of trophic positions in aquatic food webs (Post 2002). Another potential cause of uncertainty in the computation of consumer diets is the existence of ontogenic changes in the isotopic signature of some species, as in some bivalves (Rossi et al. 2004) or fish (Bode et al. 2003). We did not find significant relationships between size (as a proxy for age) and the isotopic signature in the consumers considered in this study, however. In the same way, the use of whole body samples of these animals minimized the expected differences in isotopic content among the various organs (Page \& Lastra 2003).

Finally, we used relatively low values of isotopic enrichment between primary producers and consumers, when compared to the average values $\left(\Delta \delta^{13} \mathrm{C}\right.$ between 0 and $+1 \%$, $\Delta \delta^{15} \mathrm{~N}$ between +3 and $+4 \%$ ) generally assumed in food web studies (Minagawa \& Wada 1984, Vander Zanden \& Rasmussen 2001, Post 2002). Despite mean values of trophic shift in a large range of ecosystems are similar, there is a large variability related to the relative position of the trophic levels in the food web. In this way, the trophic shift between primary producers and herbivores is highly variable for both $\delta^{13} \mathrm{C}$ and $\delta^{15} \mathrm{~N}$ (Vander Zanden \& 2001). In addition, the average $\delta^{15} \mathrm{~N}$ enrichment for consumers of invertebrates or algae is near $1.4 \%$ (McCutchan et al. 2003), a value coincident with the trophic shift observed between our phytoplankton and zooplankton samples. Low isotopic enrichment is expected in food webs dominated by omnivores, such as plankton systems (Fry \& Quiñones 1994, Rolff 2000) while a larger fractionation is expected in more complex food webs involving specialised consumers (McClelland \& Valiela 1998, Fredriksen 2003). In our case, the use of the average trophic shift values mea- 
sured between benthic producers and consumers would result in poorly constrained estimations of diets, as consumers were depleted in ${ }^{13} \mathrm{C}$ and only slightly enriched in ${ }^{15} \mathrm{~N}$ (Fig. 3). Alternatively, the use of trophic shift values from the literature did not allow for the computation of diets of most consumers, as the enrichment between all primary producers and consumers in our study was lower than average values generally reported. This implies that the consumers would lie outside the mixing polygons in the plots of Fig. 7. In any case, more information is required on the variability of trophic shifts within a particular food web, as values averaged from very different food webs may be of low applicability to local studies (McCutchan et al. 2003).

Low fractionation of isotopes would imply rapid use of limiting elements, as expected in microbial food webs (Hoch et al. 1994). Alternatively, bacteria consuming inorganic nitrogen while recycling organic carbon would provide food sources for consumers that are relatively less enriched in ${ }^{15} \mathrm{~N}$ than the original phytoplankton or macrophyte materials (Altabet 1988, Keil \& Fogel 2001). Nitrogen limitation seems unlikely in an upwelling ecosystem but bacterial uptake of inorganic nitrogen cannot be discarded, as ammonium is rapidly recycled in the study area (Bode et al. 2004a). Feeding on bacteria-derived nitrogen was suggested as an explanation of low isotopic enrichment of consumers in other marine food webs (Lovvorn et al. 2005). In the case of suspension feeders at Pantin, more depleted in ${ }^{15} \mathrm{~N}$ than those at other localities, (Fig. 7C) it must be noted that they still had $\delta^{15} \mathrm{~N}$ values $+1 \%$ higher than those of phytoplankton. As phytoplankton and sinking particles had similar ${ }^{15} \mathrm{~N}$ enrichment, it can be inferred that, on average, bacterial uptake of inorganic nitrogen was well balanced with bacterial degradation of organic nitrogen in seston particles. The low fractionation of nitrogen isotopes at Pantin suggests a large direct dependence on phytoplankton and nitrogen of marine origin, which is also reflected in the narrow shape of the mixing polygon of prey available for consumers in Fig. 7 .

As expected, suspension feeders obtained most of their nutrients from phytoplankton, notably at the exposed beach of Pantin, but at sheltered sites macrophytes contributed to almost half of their diet. The dependence on phytoplankton was also noticeable for deposit feeders at Pantin, while at sheltered sites more than $80 \%$ of their diet was originated by macrophyte material. These results contrast with those from studies in intertidal mudflats (Riera et al. 1999, Page \& Lastra 2003), which concluded a dominant role of microphytobenthos in the diet of primary consumers in estuaries. Our study area, however, has a low influence of estuarine nutrients, as indicated by the low contribu- tion of estuarine species to consumer diets. The small size of the rias considered in our study, the largest being the Ria de Ares with $72 \mathrm{~km}^{2}$, and the relatively low flow of their tributary rivers, with up to $15 \mathrm{~m}^{3} \mathrm{~s}^{-1}$, would explain these differences. The influence of estuarine sources was shown in other Galician rias, such as the Ria de Arosa (Page \& Lastra 2003), likely because of a large size $\left(230 \mathrm{~km}^{2}\right)$ and river flow $\left(93 \mathrm{~m}^{3} \mathrm{~s}^{-1}\right)$. In addition, a reduced extension of mudflats would explain the low contribution of organic matter from seagrasses. Only the consumers from Seselle, in the Ria de Ares, showed contributions of ca. $10 \%$ from seagrasses, which can be related with the relatively large size of the ria and the presence of Zostera spp. meadows nearby. In contrast, seagrasses supported a large fraction of food webs in large estuaries (e.g. Duarte \& Cebrián 1996, McClelland \& Valiela 1998).

Macroalgae are also one the main contributors, either directly or as detritus, to most primary consumers in littoral food webs. This contribution is particularly high near kelp beds (Duggins et al. 1989, Frediksen 2003), although consumers from other ecosystems also obtain most of their nutrients from macroalgae (Duarte \& Cebrián 1996, Riera \& Hubbas 2003). Because some macroalgae contain substances that are inedible or even toxic for herbivores, such as polyphenols, the bulk of organic matter derived from these producers is consumed in the form of detritus (Duggins et al. 1989). In this way, the main source for benthic consumers may be detritus derived from macroalgae, either produced in the water column (Fredriksen 2003) or from algae stranded on the shore (Riera \& Hubbas 2003). Our results confirm the importance of macroalgae even for suspension feeders at sheltered sites, but also stress the dominant role of phytoplankton in areas of large marine influence. The frequent upwelling events between March and October in the study area originate phytoplankton blooms and high inputs of organic matter through planktonic primary production (Bode et al. 2003, 2004a,b). Such inputs may override those of organic matter from macrophytobenthos, which would be of significance only at the end of summer, when most algae appear stranded on the shore and when maximum concentrations of dissolved organic matter were measured (Bode et al. 2004b). Other studies in Galician rias also noted a dominance of organic matter derived from phytoplankton in littoral food webs during blooms (Page \& Lastra 2003).

\section{Nutrient sources}

Upwelling is the main source of inorganic nutrients for coastal production in Galicia, as new nitrogen inputs were related to its elevated levels of primary pro- 
ductivity (Alvarez-Salgado et al. 2002) and to the sustaining of high mussel production (Blanton et al. 1987, Figueiras et al. 2002). Nutrients from terrestrial sources generally have a small contribution to pelagic production (Alvarez-Salgado et al. 1996, Varela \& Prego 2003) and to benthic food webs inside the rias (Page \& Lastra 2003). The relatively low flow of Galician rivers would explain its low influence although the concentration of most urban and industrial areas near the coast has been cited as the cause of local eutrophication (e.g. Varela \& Prego 2003). In our study, the relatively high $\delta^{15} \mathrm{~N}$ values measured in typical estuarine algae such as Ascophyllum nodosum may indicate an influence of anthropogenic nutrients. Furthermore, species present at all sites were more enriched in sheltered areas than in exposed ones. For instance, the chlorophyte Enteromorpha intestinalis found in the upper intertidal zone, showed the highest $\delta^{15} \mathrm{~N}$ values at the sheltered site of Mera, under the influence of the city of A Coruña. Also, the phaeophyte Cystoseira baccata, found in lower intertidal and subtidal domains, displayed a decreasing $\delta^{15} \mathrm{~N}$ enrichment from sheltered to exposed sites, suggesting a decreasing influence of sewage nitrogen towards the open sea. Other studies with stable isotopes revealed similar enrichment gradients related to the load of terrestrial nitrogen in coastal areas (McClelland \& Valiela 1998, Cole et al. 2004, Savage \& Elmgren 2004), thus revealing potential or actual eutrophication. The local eutrophication suggested by the elevated $\delta^{15} \mathrm{~N}$ values found in macroalgae agrees with the increase in nitrogen load and in the biomass of phytoplankton in semi enclosed areas of the Bay of A Coruña (Varela \& Prego 2003).

Consumer species were relatively more enriched in ${ }^{15} \mathrm{~N}$ at the sheltered sites than at the exposed site (Fig. 6), suggesting that the influence of anthropogenic nitrogen could be transmitted up the food web, as observed in other studies (McClelland \& Valiela 1998). Our study suggests that most of the nitrogen entering the analysed food webs was of marine origin, however, with anthropogenic nitrogen having relatively less importance. This is indicated not only by the low contribution of the most enriched macrophytes to the diet of the main consumers, but also by the notable contribution of phytoplankton. The influence of marine nutrients in these food webs is indicated by the relatively low enrichment of phytoplankton and some macroalgae, such as the Rhodophyceae living in the lower intertidal, which are exposed mainly to nitrogen of marine origin. These values are closer to values typical of marine nitrate (Horrigan et al. 1990) than to values of nutrients derived from terrestrial sources (Savage \& Elmgren 2004). This is supported by preliminary estimations of $\delta^{15} \mathrm{~N}$ in nitrate from marine waters off Galicia suggesting a mean value of $6.5 \%$ (Bode et al. 2003).

\section{CONCLUSIONS}

The analysis of natural stable isotope abundances allowed us to verify the dominant flows of nutrients and organic matter along the food web in Fig. 1. First, new nitrogen inputs from upwelling are important not only to phytoplankton but also to macroalgae. Despite the influence of sewage-derived nutrients that was inferred from nitrogen isotope abundances in characteristic estuarine macrophytes (mainly Chlorophyceae and Phaeophyceae), potential eutrophication by anthropogenic nutrients seems limited to areas near large cities. The dominance of anthropogenic versus marine nitrogen can be also traced in primary consumers despite large variability in available diets. Second, both suspension and deposit feeders depend on phytoplanktonic organic matter. Macroalgae contributed to a large fraction of the diet of benthic intertidal consumers inside the rias, but phytoplankton contribution increased outside the rias. Third, due to the large variability in isotopic composition of prey, a clear preference for suspension or deposit feeders cannot be demonstrated for Nucella lapillus, although the isotopic signature in this benthic predator reflects local variability in food webs. Finally, this study showed an unexpected variability of local food webs in the Galician upwelling, likely due to adaptations to the available nutrients, and characterised by low isotopic fractionation between producers and consumers.

These results indicate a dominant role of marine sources of nutrients for supporting littoral food webs, with a large influence of phytoplankton even inside the rias. Due to the large seasonal variations in the upwelling (Alvarez-Salgado et al. 1996, Bode et al. 1998, 2004a,b), and the different nutrient regime in the northern and southern rias of Galicia (Prego et al. 1999), the variability in isotopic signatures of both primary producers and consumers is expected to change not only at spatial but also at temporal scales. This variability would require further research to determine whether changes in littoral food webs of upwelling ecosystems, primarily driven by the regional oceanography, are being modified by the increasing input of anthropogenic nutrients.

Acknowledgements. We thank J. Lorenzo, I. González and E. Rey for assistance in the collection of plankton and sediment trap samples. The collaboration of M. Bode in the sampling of benthic species is also appreciated. Isotopic analyses were made at the SXAIN of the Universidad de A Coruña by M. Lema. The final version of the manuscript benefited from the valuable comments of 5 anonymous referees. This research was funded in part by the programme RADIALES (IEO), and by projects PELASSES (99/10), and SARDYN (QLRT2001-00818) of the European Union. This is a contribution to the GLOBEC-Spain Programme. 


\section{LITERATURE CITED}

Altabet MA (1988) Variations in nitrogen isotopic composition between sinking and suspended particles: implications for nitrogen cycling and particle transformation in the open ocean. Deep-Sea Res 35:535-554

Alvarez-Salgado XA, Rosón G, Pérez FF, Figueiras FG, Rios AF (1996) Nitrogen cycling in an estuarine upwelling system, the Ria de Arousa (NW Spain). 2. Spatial differences in the short-time-scale evolution of fluxes and net budgets. Mar Ecol Prog Ser 135:275-288

Alvarez-Salgado XA, Beloso S, Joint I, Nogueira E and 6 others (2002) New production of the NW Iberian shelf during the upwelling season over the period 1982-1999. Deep Sea Res 49:1725-1739

Barbara I, Cremades J (1996) Seaweeds of the Ria de A Coruña (NW Iberian Peninsula, Spain). Bot Mar 39:371-388

Blanton JO, Tenore KR, Castillejo F, Atkinson LP, Schwing FB, Lavin A (1987) Relationship of upwelling to mussel production in the rias of the western coast of Spain. J Mar Res 45:497-511

Bode A, Alvarez-Ossorio MT (2004) Taxonomic versus trophic structure of mesozooplankton: a seasonal study of species succession and stable carbon and nitrogen isotopes in a coastal upwelling ecosystem. ICES J Mar Sci 61:563-571

Bode A, Varela M, Barquero S, Alvarez-Ossorio MT, González N (1998) Preliminary studies on the export of organic matter during phytoplankton blooms off La Coruña (North Western Spain). J Mar Biol Assoc UK 78:1-15

Bode A, Carrera P, Lens S (2003) The pelagic foodweb in the upwelling ecosystem of Galicia (NW Spain) during spring: natural abundance of stable carbon and nitrogen isotopes. ICES J Mar Sci 60:11-22

Bode A, Barquero S, González N, Alvarez-Ossorio MT, Varela M (2004a) Contribution of heterotrophic plankton to nitrogen regeneration in the upwelling ecosystem of A Coruna (NW Spain). J Plankton Res 26:1-18

Bode A, Varela MM, Teira E, Fernández E, González N, Varela M (2004b) Planktonic carbon and nitrogen cycling off NW Spain: variations in production of particulate and dissolved o-rganic pools. Aquat Microb Ecol 37:95-107

Cole ML, Valiela I, Kroeger KD, Tomasky GL and 5 others (2004) Assessment of a $\delta^{15} \mathrm{~N}$ isotopic method to indicate anthropogenic eutrophication in aquatic ecosystems. J Environ Qual 33:124-132

Duarte CM, Cebrián J (1996) The fate of marine autotrophic production. Limnol Oceanogr 41:1758-1766

Duggins DO, Simenstad CA, Estes, JA (1989) Magnification of secondary production by kelp detritus in coastal marine ecosystems. Science 245:170-173

Figueiras FG, Labarta U, Fernández Reiriz MJ (2002) Coastal upwelling, primary production and mussel growth in the Rías Baixas of Galicia. Hydrobiologia 484:121-131

France RL (1995) Carbon-13 enrichment in benthic compared to planktonic algae: foodweb implications. Mar Ecol Prog Ser 124:307-312

Fredriksen S (2003) Food web studies in a Norwegian kelp forest based on stable isotope $\left(\delta^{13} \mathrm{C}\right.$ and $\left.\delta^{15} \mathrm{~N}\right)$ analysis. Mar Ecol Prog Ser 260:71-81

Fry B, Quiñones RB (1994) Biomass spectra and stable isotope indicators of trophic level in zooplankton of the Northwest Atlantic. Mar Ecol Prog Ser 112:201-204

Hoch MP, Fogel ML, Kirchman DL (1994) Isotope fractionation during ammonium uptake by marine microbial assemblages. Geomicrobiol J 12:113-127

Horrigan SG, Montoya JP, Nevins JL, McCarthy JJ, Ducklow H, Goericke R, Malone T (1990) Nitrogenous nutrient transformations in the spring and fall in the Chesapeake Bay. Estuar Coast Shelf Sci 30:369-391

Jacob U, Mintenbeck K, Brey T, Knust R, Beyer K (2005) Stable isotope food web studies: a case for standardized sample treatment. Mar Ecol Prog Ser 287:251-253

Keil RG, Fogel ML (2001) Reworking of amino acid in marine sediments: stable isotopic composition of amino acids in sediments along the Washington coast. Limnol Oceanogr 46:14-23

Kerner M, Spitzy A (2001) Nitrate regeneration coupled to degradation of different size fractions of DON by the picoplankton in the Elbe estuary. Microb Ecol 41:69-81

Kübler JE, Raven JA (1994) Consequences of light limitation for carbon acquisition in 3 rhodophytes. Mar Ecol Prog Ser 110:203-209

Lovvorn JR, Cooper LW, Brooks ML, De Ruyck CC, Bump JK, Grebmeier JM (2005) Organic matter pathways to zooplankton and benthos under pack ice in late winter and open water in late summer in the north-central Bering Sea. Mar Ecol Prog Ser 291:135-150

Mann KH (1988) Production and use of detritus in various freshwater, estuarine, and coastal marine ecosystems. Limnol Oceanogr 33:910-930

McClelland JW, Valiela I (1998) Changes in food web structure under the influence of increased anthropogenic nitrogen inputs to estuaries. Mar Ecol Prog Ser 168:259-271

McCutchan JH, Lewis WMJ, Kendall C, McGrath CC (2003) Variation in trophic shift for stable isotope ratios of carbon, nitrogen, and sulfur. Oikos 102:378-390

Minagawa M, Wada E (1984) Stepwise enrichment of ${ }^{15} \mathrm{~N}$ along food chains: further evidence and the relation between $\delta^{15} \mathrm{~N}$ and animal age. Geochim Cosmochim Acta 48:1135-1140

Montoya JP, McCarthy JJ (1995) Isotopic fractionation during nitrate uptake by phytoplankton grown in continuous culture. J Plankton Res 17:439-464

Niell FX (1977a) Distribución y zonación de las algas bentónicas en la facies rocosa del sistema intermareal de las Rias Bajas Gallegas. Invest Pesq 41:219-237

Niell FX (1977b) Rocky intertidal benthic systems in temperate seas: a synthesis of their functional performances. Helgol Wiss Meeresunters 30:315-333

O'Reilly CM, Hecky RE, Cohen AS, Plisnier PD (2002) Interpreting stable isotopes in food webs: recognizing the role of time averaging at different trophic levels. Limnol Oceanogr 47:306-309

Page HM, Lastra M (2003) Diet of intertidal bivalves in the Ría de Arosa (NW Spain): evidence from stable $\mathrm{C}$ and $\mathrm{N}$ isotope analysis. Mar Biol 143:519-532

Phillips DL, Gregg JW (2001) Uncertainty in source partitioning using stable isotopes. Oecologia 127:171-179

Phillips DL, Gregg JW (2003) Source partitioning using stable isotopes: coping with too many sources. Oecologia 136: 261-269

Post DM (2002) Using stable isotopes to estimate trophic position: models, methods, and assumptions. Ecology 83: 703-718

Prego R, Barciela MC, Varela M (1999) Nutrient dynamics in the Galician coastal area (Northwestern Iberian Peninsula): Do the Rias Bajas receive more nutrient salts than the Rias Altas? Cont Shelf Res 19:317-334

Raven JA, Johnston AM, Kuebler JE, Korb R, and 8 others (2002) Mechanistic interpretation of carbon isotope discrimination by marine macroalgae and seagrasses. Funct Plant Biol. 29:2-3

Riera P, Hubas C (2003) Trophic ecology of nematodes from various microhabitats of the Roscoff Aber Bay (France): 
importance of stranded macroalgae evidenced through $\delta^{13} \mathrm{C}$ and $\delta^{15} \mathrm{~N}$. Mar Ecol Prog Ser 260:151-159

Riera P, Stal LJ, Nieuwenhuize J, Richard P, Blanchard G, Gentil F (1999) Determination of food sources for benthic invertebrates in a salt marsh (Aiguillon Bay, France) by carbon and nitrogen stable isotopes: importance of locally produced sources. Mar Ecol Prog Ser 187:301-307

Rolff C (2000) Seasonal variation in $\delta^{13} C$ and $\delta^{15} \mathrm{~N}$ of sizefractionated plankton at a coastal station in the northern Baltic proper. Mar Ecol Prog Ser 203:47-65

Rossi F, Herman PMJ, Middelburg JJ (2004) Interspecific and intraspecific variation of $\delta^{13} \mathrm{C}$ and $\delta^{15} \mathrm{~N}$ in depositand suspension-feeding bivalves (Macoma balthica and Cerastoderma edule): Evidence of ontogenetic changes in feeding mode of Macoma balthica. Limnol Oceanogr 49: 408-414

Savage C, Elmgren R (2004) Macroalgal (Fucus vesiculosus) $\delta^{15} \mathrm{~N}$ values trace decrease in sewage influence. Ecol Appl $14: 517-526$

Savoye N, Aminot A, Tréguer P, Fontugne M, Naulet $N$, Kérouel R (2003) Dynamics of particulate organic matter $\delta^{15} \mathrm{~N}$ and $\delta^{13} \mathrm{C}$ during spring phytoplankton blooms in a macrotidal ecosystem (Bay of Seine, France). Mar Ecol

Editorial responsibility: Howard I. Browman (Associate Editor-in-Chief), Storebø, Norway
Prog Ser 255:27-41

Valiela I (1995) Marine Ecological Processes. SpringerVerlag, New York

Vander Zanden MJ, Rasmussen JB (2001) Variation in $\delta^{15} \mathrm{~N}$ and $\delta^{13} \mathrm{C}$ trophic fractionation: implications for aquatic food web studies. Limnol Oceanogr 46:2061-2066

Varela M, Penas E (1985) Primary production of benthic microalgae in an intertidal sand-flat of the Ria de Arosa, NW Spain. Mar Ecol Prog Ser 25:111-119

Varela M, Prego R (2003) Hydrography and phytoplankton in an isolated and non-pristine ria area: the A Coruña Harbour (NW Spain). Acta Oecol 24:113-124

Varela M, Fuentes JM, Penas E, Cabanas JM (1984) Producción primaria de las Rías Baixas de Galicia. Cuad Area Cienc Mar Sem Estud Gal 1:173-182

Williams PM, Robertson KJ, Soutar A, Griffin SM, Druffel ERM (1992) Isotopic signatures $\left({ }^{14} \mathrm{C}_{,}{ }^{13} \mathrm{C},{ }^{15} \mathrm{~N}\right)$ as tracers of sources and cycling of soluble and particulate organic matter in the Santa Monica Basin, California. Prog Oceanogr 30:254-290

Wooster WS, Bakun A, McLain DR (1976) The seasonal upwelling cycle along the eastern boundary of the North Atlantic. J Mar Res 34:131-141

Submitted: October 19, 2005; Accepted: January 11, 2006

Proofs received from author(s): July 18, 2006 